\title{
離岸流と海岸変形の相互作用に関する研究

\author{
Interactions of rip currents and coastal bathymetry change
}

\author{
細山田得三 ${ }^{1} \cdot$ 村川はる ${ }^{2} \cdot$ 犬飼直之 $^{3}$ \\ Tokuzo HOSOYAMADA, Harumi MURAKAWA and Naoyuki INUKAI
}

\begin{abstract}
Temporal interactions of shapes of rip current and coastal bathymetries are studied with numerical wave simulation. Boussinesq equations for coastal waves, which involve coastal currents as a solution, are combined with equations of littoral drift and deformation of coastal bathymetry. Uniform slope and the beach cusp with regular spacing are used as typical model coastal geography, and Tayuhama beach located in Niigata city, where the in situ rip current was observed, was used as objective of field scale simulation. Results show that interaction between currents and bathymetry change enhances the rip currents more than the case with constant bathymetry. The shapes of rip currents and bathymetrical changes obtained by the numerical study agree with theoretical study by Hino.
\end{abstract}

\section{1. はじめに}

離岸流は，海岸波動の非線形性によって岸側に輸送さ れた海水が局所的な地点において沖へ戻る際に形成され る強い流れであり，海難事故の原因となるため社会的関 心が高い. 離岸流を含む沿岸域における海浜流系は海浜 地形形状の影響を強く受けるが，逆に流れが地形変化を 引き起こし, rip channelやカスプなどの特異な地形形状 が形成される.沿岸域は波・流れ・地形の協働現象が支 配する場であり，海浜地形や景観にカオス的な自然造形 を形成し興味深い。海浜流系の流れの中でも離岸流は特 に強い流れであり，七ル構造と呼ばれる規則正しい循環 流を形成してそれに応じて汀線付近に凹凸を有する規則 的なカスプ地形が生じる（椹木，1982）.

離岸流の研究は古くから観測を主体とした研究が続け られており, 個々の事例報告が積み上げられてきている. 例えば, 離岸流の現地観測として, 出口ら（2003）が, 鳥取県浦富海岸で係留気球からのビデオ撮影と極浅海域 に設置した流速計による離岸流の実測を行い，潜堤開口 部背後において, 入射波高の増大に伴う顕著な地形性の 離岸流を観測した。西ら（2003）も，宮崎県青島海岸で の小型フロートでの漂流観測を行い, 離岸流発生箇所の 特定が可能であること示した. 海外においては, 数值モ デルの妥当性の確認を目的とした実海域計測が精力的に 実施されている（Castelleら，2009）。しかしながらいず れの研究においても普遍的な実態や発生のメカニズムに ついては十分な知見が得られているとは言えない.さら にその先の離岸流と海岸変形の相互作用についての研究 は未だ不十分と言わざるを得ないが，1970年代に日野に

\begin{tabular}{llll}
\hline 1 & 正会員 & 工博 & 長岡技術科学大学 環境 $\cdot$ 建設系教授 \\
2 & & 工修 & 鹿島建設北陸支店 \\
3 & 正会員 & 工博 & 長岡技術科学大学 環境 $\cdot$ 建設系 助教
\end{tabular}

よって流れの安定解析を応用した理論研究が展開され た.この研究成果により波の代表的な諸元や平均的な海 浜地形勾配などの外部的な条件を入力して最も成長する 離岸流の形状や地形変形を予測する手法が示された。日 野（1974 a, b）の理論解析では, 波の入射は汀線に対し て斜めである必要があり, 完全に対称な直行方向入射波 を取り扱うことができない。流れの安定性問題において しばしば引用されるべナール対流は容器や外力の条件の 対称性を最大限に仮定した上でそれを破る非対称性とし てのセル構造を論じるものである. それに比して流れを 駆動する波の入射方向の条件に始めから非対称性が含ま れることは理論の限界を提示していると思われる。一方, 数值計算では精度の限界として例えば浮動小数点表示の 有効桁以下の精度が保証されないが, 室内実験や観測に 比べてかなり高い対称性の条件を設定することが可能で ある.しかしながら今のところ, 数值計算による離岸流 と地形の相互作用に関する既往研究の事例は十分ではな いと思われる。本研究では, 波動とそれによって引き起 こされる離岸流と地形変化のそれぞれのモデルを結合 し, それらの相互作用について数值モデルを用いた基礎 的な研究を行った。海底地形はモデル地形として一様勾 配およびカスプ地形を対象とし, 種々の単一方向規則波 を入射波浪条件として計算を行った。計算結果の考察と して日野の理論解析の結果と比較・検討した. また, 新 潟市郊外の太夫浜における実地形を用いた計算も実施 し, 実地観測と比較して妥当性の検証も行った。

\section{2. 数值モデルの概要}

従来の数值計算では海浜流の計算は, ラジエーション ストレスなどを評価するために波動の周期に比して長い 時間平均を求める必要があった。このため波動と海浜流 の時間分解能に差異が生じ, 海浜流や地形変動を調べる 
ためには時間スケールの長い現象を解析対象とせざるを 得なかった。これは地形の季節的な変動のようなさらに 長時間スケールの現象を論じるような場合，適当な手法 となるが, 発生してから消滅までの時間が最大でも数時 間程度の離岸流の解析手法としては不向きであると判断 した。 そこで本研究では, 海浜流と地形変化の相互作用 を同一時間スケールで評価するために，毎計算ステップ で，1. 波・海浜流の計算，2. 底質移動および海底地形変 化の計算，3. 地形の修正を行った。これは，実海岸にお いて波, 海浜流, 地形変化といった現象が同時に発生し, 密接に相互作用していると考えられるためである.

波と海浜流の計算に用いた式は修正ブシネスク方程式 であり，砕波を含む波の非線形性によって生じる諸現象 を解くことができる。従って各時間ステップで求められ た波動成分を時間積分すれば海浜流を評価することがで きる、本研究では海浜流の成分を抽出して計算に利用す ることはせず，毎時間ステップで計算される波動成分と しての流速によって地形変動を逐時的に計算した。この 手法により, 地形変動は過去の履歴を積み重ねることに なり, 波動成分の平均としての海浜流による地形変動と 等価であると見なすことができる.

底質移動および海底地形変化の計算は, Bailard（1981） によって提案された，流れによって生じる砂の移動（掃 流砂，浮遊砂）を考慮したモデルを用いて計算を行った. 式（1）によって掃流砂量を，式（2）によって浮遊砂量 を計算し，式（3）によって体積漂砂量を求めた。

$$
\begin{aligned}
& \vec{q}_{B}=\frac{C_{f} \varepsilon_{B}}{\left(\rho_{s} / \rho-1\right) g \tan \phi}\left(\vec{u}_{b}\left|\vec{u}_{b}\right|^{2}-\frac{s}{\tan \phi}\left|\vec{u}_{b}\right|^{3} \vec{i}\right) \cdots \cdots(1) \\
& \vec{q}_{S}=\frac{C_{f} \varepsilon_{S}}{\left(\rho_{s} / \rho-1\right) g w_{S}}\left(\vec{u}_{b}\left|\vec{u}_{b}\right|^{3}-\frac{\varepsilon_{S}}{w_{S}}\left|\vec{u}_{b}\right|^{5} \vec{i}\right) \cdots \cdots \cdots(2) \\
& \vec{q}=\vec{q}_{B}+\vec{q}_{s} \cdots \cdots \cdots \cdots \cdots \cdots \cdots \cdots \cdots \cdots \cdots \cdots \cdots \cdots \cdots \cdots \cdots \cdots \cdots \cdots \cdots \cdots \cdots \cdots(3)
\end{aligned}
$$

ここで, $q$ は体積漂砂量 $\left(\mathrm{m}^{2} / \mathrm{s}\right), q_{B}$ は掃流砂量 $\left(\mathrm{m}^{2} / \mathrm{s}\right)$, $q_{S}$ は浮遊砂量 $\left(\mathrm{m}^{2} / \mathrm{s}\right), \rho_{S}$ は底質の密度 $\left(2600 \mathrm{~kg} / \mathrm{m}^{3}\right), \rho$ は水の密度 $\left(1030 \mathrm{~kg} / \mathrm{m}^{3}\right), C_{f}$ は抗力係数 $0.01, \phi$ は底質の 内部摩擦角 $0.1, s$ は海底勾配， $i$ は底面における局所的な 斜面を登る向きの単位ベクトル， $\varepsilon_{B}, \varepsilon_{S}$ はそれぞれ掃流 砂, 浮遊砂に対する無次元定数 $0.13,0.025, u_{b}$ は底面流 速 $(\mathrm{m} / \mathrm{s}), w_{s}$ は底質の沈降速度 $(0.005 \mathrm{~m} / \mathrm{s})$ である.

そして式（3）によって求められた体積漂砂量を局所 的な勾配の影響を考慮した修正式（4）によって修正し， 底質の連続式（5）で地形変化の計算を行った。

$$
\begin{aligned}
& \vec{q}_{m}=\vec{q}+\varepsilon|\vec{q}| \nabla \cdot z_{b} \\
& \frac{\partial z_{b}}{\partial t}=(\lambda-1) \nabla \cdot \vec{q}_{m}
\end{aligned}
$$

表-1 地形および入射波の計算条件

\begin{tabular}{cc|c}
\hline 地形 & $\begin{array}{c}\text { カスプ地形 } \\
\text { - 沿岸波長 } 200 \mathrm{~m}, \text { 岸沖振幅 } 60 \mathrm{~m} \text { ) }\end{array}$ \\
\hline 地形勾配 & $s$ & $1 / 10, \quad 1 / 30,1 / 50$ \\
\hline 波高 $(\mathrm{m})$ & $H$ & $0.5 \sim 1.5$ \\
\hline 周期 $(\mathrm{s})$ & $T$ & $3 \sim 12$ \\
\hline 波向 $\left.{ }^{\circ}{ }^{\circ}\right)$ & $\theta$ & 0 : 直角入射, 45 \\
\hline
\end{tabular}

ここで, $q_{m}$ は局所漂砂量 $\left(\mathrm{m}^{2} / \mathrm{s}\right), \varepsilon(=0.5)$ は局所的な 勾配の影響を表す係数， $\lambda\left(=0.4 ）\right.$ は底質の空隙率， $z_{b}$ は 地盤高 $(\mathrm{m})$ である. また、局所的に生じた安息角以上 の急斜面を補正するためのアルゴリズムも含まれている.

\section{3. 計算条件}

地形条件，および波浪条件による離岸流発生の違いを 検討するため，表-1に示すように条件を変化させ計算を 行った。波浪は単一方向規則波とし，周期と波高を種々 変化させて計算した。

計算領域は，沿岸方向に $1600 \mathrm{~m} ，$ 岸沖方向に $800 \mathrm{~m}$ の矩 形領域である．差分計算のための格子は $4 \mathrm{~m} \times 4 \mathrm{~m}$ の正方 形とし，格子数は沿岸，岸沖方向それぞれ $400 \times 200$ 個 である。入射波は計算領域の沖側境界の直線上で与え， 計算領域の側方はゾンマーフェルトの放射条件およびス ポンジ層による吸収条件を付加して側方からの反射の影 響を極力低減させた。造波開始後，計算領域全体が定常 状態になることを確認したうえで，造波200秒後に地形 変化の計算を開始した (移動床)。計算ケースの一部に は地形変化を含まないケースが含まれている（固定床）.

\section{4. 計算結果}

結果の表示は，いずれも側方境界の影響が十分小さい

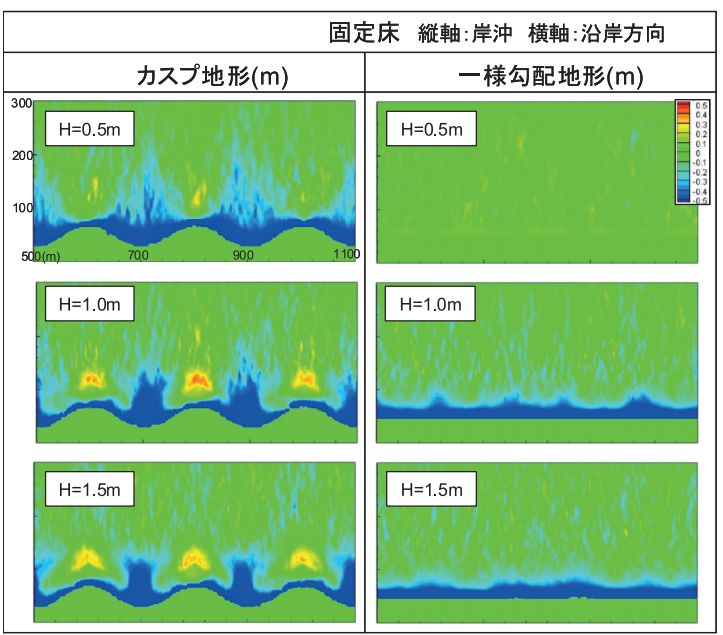

図-1 波高による離岸流流速の分布の違い（固定床） 左段：カスプ地形, 右段：一様勾配地形, $T=5 \mathrm{sec}, \theta=0^{\circ}, s=1 / 10$ 


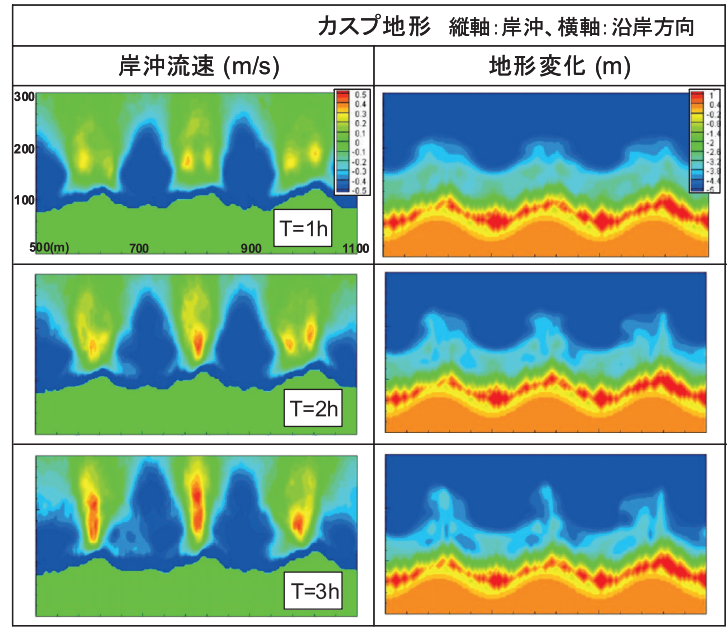

図-2 離岸流の時間発展（移動床 カスプ地形） 左段：岸沖流速, 右段 : 地形変化, $T=12 \mathrm{sec}, \theta=0^{\circ}, s=1 / 30$

と考えられる計算領域の中央部の汀線を含む沿岸方向 $500 \sim 1100 \mathrm{~m}$ ，岸沖方向 $0 \sim 300 \mathrm{~m}$ とした.これは全計算 領域の $14 \%$ 程度である。

\section{a）固定床で発生した離岸流}

図-1では固定床において, 波高の変化に対する離岸流 の形成についてカスプ地形と一様勾配地形を比較してい る.カスプ地形では, 凸部に離岸流と見られる強い沖向 き流れが明瞭に発生した. カスプ凸部の両脇の凹部から 凸部方向に曲がった波と流れは, 凸部先端から沖側の強 い流れを生じそれがセル構造を形成し，その循環流が離 岸流へ発達した。図は地形勾配 $s$ が $1 / 10$ と本研究の条件

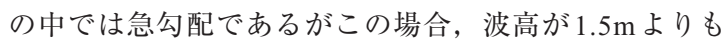
$1.0 \mathrm{~m}$ のほうが離岸流速は大きい. 図には示していないが 周期についても 12sよりも8sのケースの方が離岸流の流 速は大きい. 堀川（1973）等で得られている一般的知見 は波高・周期の増大とともに離岸流の流速や形状が大き くなるということである.地形勾配が緩やかな場合には その傾向を確認したが, 急勾配になると離岸流が極大と なる波高・周期が存在することが示唆された。一様勾配 地形ではカスプ地形ほどの顕著な沿岸方向の分布構造は 見られないが, 汀線付近の流速が沿岸方向に変動してい る.これは離岸流の萌芽的な構造である可能性があるが, 現時点では判断することは困難である.

\section{b）離岸流による地形変化（移動床）}

離岸流と地形変化の相互作用を調べるため 3 時間にわ たる地形変化を計算した，計算結果より，波高が小さく 周期の短いケースについては顕著な地形変化は見られな かったが, 高波高, 長周期の波浪条件において地形と海 浜流に顕著な時間的変化が生じた. 以下, 離岸流および 地形変化が顕著であったケースに絞って考察する.

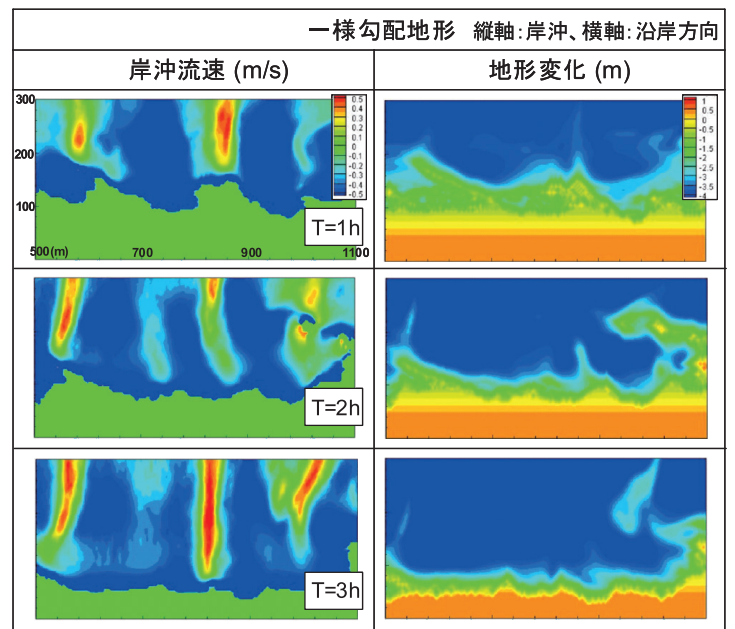

図-3 離岸流の時間発展（移動床一様勾配地形） 左段：岸沖流速，右段：地形変化, $T=12 \mathrm{sec}, \theta=0^{\circ}, s=1 / 50$

図-2 は初期地形勾配 $s=1 / 30$ のカスプ地形に, 波向 $0^{\circ}$, 波高 $H=1.5 \mathrm{~m}$, 周期 $T=12$ 秒の波を 3 時間作用させた結果 である。カスプ凹部沖では侵食され，カスプ凸部沖では 砂が徐々に堆積した。離岸流流速は波の作用開始 1 時間 後に $0.2 \mathrm{~m} / \mathrm{s}$ 程度であったが, 3 時間後には $0.5 \mathrm{~m} / \mathrm{s}$ 程度の成 長した。これはセル構造において, 凹部の沖から岸向き の海浜流によって輸送された土砂が, 汀線付近に堆積し, さらに沖へ向かう離岸流によって凸部の沖へ輸送され堆 積したものと考えられる. その結果, 波が強く屈折する 領域が沖へと移動し, 岸に向かうエネルギーが小さくな ったことで離岸流が発達したと考えられる。

図-3には初期地形勾配 $s=1 / 50$ の一様勾配地形に, $\theta=0^{\circ}$, $H=1.5 \mathrm{~m}, T=12$ 秒の波を 3 時間作用させた結果である. 波 の作用開始 1 時間後に一様勾配だった地形が波状の地形 になり，その後徐々に汀線が後退した。 また流速につい ては 1 時間で離岸流の分布範囲が狭く流速が強いものと なり，2時間後に一旦は流速が弱くなったが，3時間後に はまた沖方向に長く伸びる非常に強い離岸流が形成され ている。一様勾配地形については固定床の場合, 図-1の 右段に示すようにカスプ地形ほどの明確は沿岸方向の構 造は見られないが, 微小な凹凸を見出すことはできる. 移動床の場合, これが流れに従って変形する地形と協働 して大規模な離岸流へと発達したと考えられる.

また，カスプ・一様勾配地形のどちらのケースにおい ても固定床の計算時には生じなかった, 離岸流流速の時 間的な変化や発生箇所の変化が生じている. 地形変化は 離岸流の発達・形成に強い影響を与えるということが分 かる. 堀川による現地調査結果の要約によれば, 離岸流 の流速は時間とともに変動することが報告されており, それが海底地形の変動によることが予測される。 

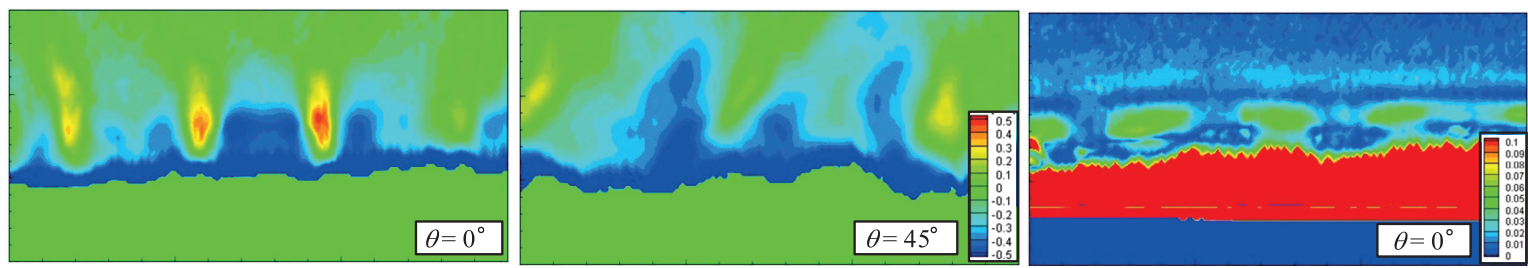

図-4 理論解析との比較のための計算結果（移動床）（岸沖・沿岸方向分布） 左：岸沖流速 $\left(\theta=0^{\circ}\right)(\mathrm{m} / \mathrm{s})$, 中：岸沖流速 $\left(\theta=45^{\circ}\right)(\mathrm{m} / \mathrm{s})$ 右：砕波係数分布 $\left(\theta=0^{\circ}\right) \quad T=12 \mathrm{sec}, H=1.5 \mathrm{~m}, s=1 / 30$

本論文では示していないが，地形勾配 $s$ の変化に対す る離岸流の形成についても検討しており，sが小さく勾 配が緩やかなほど，地形や岸沖流速の沿岸方向変化が生 じやすいことを確認した。これは堀川らによる現地調査 結果の知見と一致している.

\section{c）日野による理論解析との比較}

離岸流と地形変化との関係については, 日野（1974a, b）によって以下のような理論解析結果が示されている.

1. 入射角度が大きくなり，斜め入射となる場合，ピーク 波数は小さく，離岸流セルの間隔が大きい.

2. 離岸流セルの波長は，汀線から碳波帯までの距離 $L_{b}$ の 2〜4 倍程度である.

3. $h_{b}$ を砕波帯での水深としてパラメー夕 $\left(h_{b} / L_{b}\right)$ が小さ く, 海底地形勾配が小さいほど，地形変化の増幅率の 值が大きくなる。（遠浅の海岸ほど離岸流やカスプ地 形がよく発達する.）

4. 凸型地形ほど離岸流の発生が顕著である。

結果3., 4.は今回の解析結果においても多くのケース で再現された，さらに1., 2.についても比較を行った。

結果1.の入射射角度による離岸流セルの間隔について 検証するため, $s=1 / 30$ の一様勾配地形に, $H=1.5 \mathrm{~m}, T=12$ 秒, そして波向 $\theta=0^{\circ}, 45^{\circ}$ と変化させ 3 時間の計算を行っ た。それぞれの造波 3 時間後における流速分布図を図-4 左抢よび中央に示す， $\theta=0^{\circ}$ の場合，離岸流の発生間隔は $140 \mathrm{~m}$ 程度であり，地形の凸型もこの間隔で形成されてい た。一方， $\theta=45^{\circ}$ として斜め入射の条件で計算した場合， 離岸流の発生間隔は $240 \mathrm{~m}$ 程度となり, $\theta=0^{\circ}$ の時と比べ て離岸流セルの間隔が大きくなっていることが分かり日 野の理論との整合性が確認できる.

次に結果2.の離岸流セルの波長について検証するため, $s=1 / 30$ の一様勾配地形に, $H=1.5 \mathrm{~m}, T=12$ 秒, $\theta=0^{\circ}$ とし 3 時間の計算を行った。計算開始 3 時間後の砕波係数分布 を図-4右に示す．汀線から砕波带までの距離が70m 程度 であるのに対し, 離岸流セルの波長は $140 \mathrm{~m}$ 程度と汀線 から䂗波带までの距離の約 2 倍であった。離岸流セルの 波長は, 汀線から砕波帯までの距離 $L_{b}$ の2 倍程度となり,

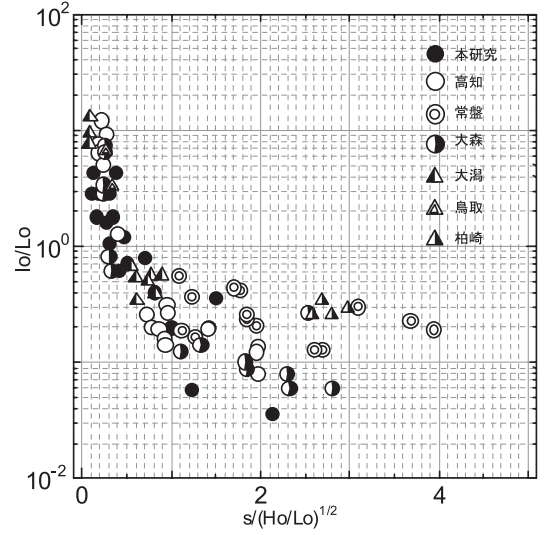

図-5 離岸流セルの形状について既往研究との比較

これは日野の結論2.「離岸流セルの波長は，汀線から砕 波帯までの距離 $L_{b}$ の $2 \sim 4$ 倍程度である.」と概ね一致し ている.

本研究で得られた種々の離岸流のセル構造とこれまで 現場で観測されたものとの一致性について検討する必要 がある．離岸流セルの沿岸方向の間隔を $l_{o}$ とし， $H_{o}, L_{o}$ を それぞれ沖波波高と沖波波長とする。従来の研究では無 次元パラメータ $l_{o} / L_{o}$ を縦軸として横軸をイリバーレン数 $s /\left(H_{o} / L_{o}\right)^{1 / 2}$ とした図-5によって両者の依存関係が整理さ れている. 本数值実験によって形成された離岸流七ルの 形状とイリバーレン数の関係を調べた結果, 従来観測で 得られた分布と十分よく一致しており，本研究の知見を 現場の現象に適用できることが示された.

\section{d）実地形計算}

新潟県島見浜付近（太夫浜）を対象とし, 離岸流の再 現計算を行った．計算領域は海岸線方向に $800 \mathrm{~m} ，$ 沖方向 に $400 \mathrm{~m}$ とした。図-6の左端はデータより作成した地形 図である.現地には突堤などのコンクリートの海洋構造 物が設置されている。この地点において, 海上保安庁第 九管区海上保安本部が離岸流観測調查を行った, 平成 18 年 5 月 25 日の波浪を作用させ，計算を行った。当日の波 浪は波向きが北北西，波高 $\mathrm{H}$ が $0.5 \sim 1.0 \mathrm{~m}$ ，周期 $T$ を 5 秒 とし15 分程度の海浜流と地形変化の計算を行った。計算 結果として，図-6の中央に流速分布図を，図-6の右端に 計算後の地形標高を示す。流速分布図より, 図の中央部 

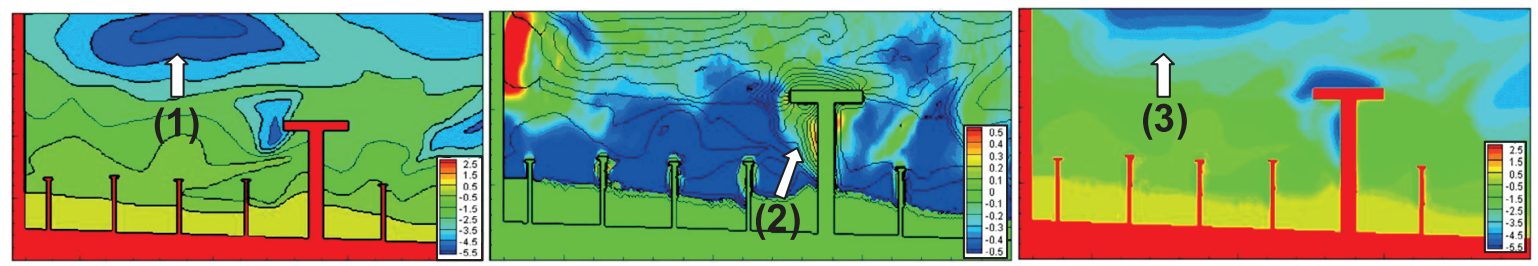

図-6 新潟県島見浜を対象とした計算（岸沖・沿岸方向分布）

左：地形標高 $(\mathrm{m})$, 中央：岸沖方向流速 $(\mathrm{m} / \mathrm{s})$, 右 : 計算後の地形標高 $(\mathrm{m} / \mathrm{s})$

の T字型の突堤付近から $0.3 \mathrm{~m} / \mathrm{s} \sim 0.4 \mathrm{~m} / \mathrm{s}$ 程度の離岸流が 発生している（矢印 (2)). また, 計算領域中の左端は 長い突堤があり，そこでは流速が大きい離岸流が形成さ れ, それに伴う地形変化が確認できる. 計算領域の沖側 での地形が急激に浅くなっている事が目立つ（矢印 (1), (3)）が, 造波境界が近く, 波が実海域とやや異なるこ とが原因ではないかと考えられる。海底地形変化の最終 的な一致性については, 現地での測量結果がないため確 認できなかった。この日，付近の突堤で行われた離岸流 の観測では， $0.2 \mathrm{~m} / \mathrm{s}$ から $0.4 \mathrm{~m} / \mathrm{s}$ の流速が観測されており， これは解析の結果形成された離岸流の流速のオーダーと 合致している.

\section{5. まとめ}

海岸波動によって生じる離岸流と海岸変形の相互作用 について検討を行うことを目的とし，様々な波浪条件， および地形条件について基礎的な数值解析を行った. 特 に一様勾配地形からのカスプ地形生成に至るまでの離岸 流の影響について検討した.

本研究の結果, カスプ地形では固定床の場合でも離岸 流が発生した。一様勾配地形の固定床では，計算条件が 対称となるため明確な離岸流を見出すことはできなかっ た.しかしながら, 計算結果に沿岸方向のゆらぎが生じ, 現時点では明確ではないが，そのゆらぎが離岸流に発展 する可能性がある. 計算機の有効桁数以下の打ち切り誤 差がこのゆらぎを誘起している可能性を否めない. 本研 究はすべて単精度で計算しているが、倍精度で計算して もそのレベルでの打ち切り誤差の問題が生じる．単精度 と倍精度の計算結果を比較して打ち切り誤差の影響を比 較検討することは今後の研究課題としたい.

地形変化を考慮する場合（移動床）の計算は, 固定床 と比べて大きな違いがあることが分かった。 カスプ地形 の場合，いずれの場合もカスプの凸部において沖向きの 流れが生じる点は同じであったが, 地形変化に応じた離 岸流の形態の変動を確認した。一様勾配地形の場合, 固 定床では前述の通り，離岸流の萌芽を確認するのみであ ったが，移動床では大きな地形変動とそれに伴う離岸流 セルの発生と時間変動を確認した。移動床の場合には地
形勾配 $s=1 / 50$, 波高 $H=1.5 \mathrm{~m}$, 周期 $T=12$ 秒という計算ケ ースの中では緩勾配, 高波高, 長周期の条件において $0.5 \mathrm{~m} / \mathrm{s}$ 程度の強い離岸流が生じることが分かった.

日野の理論解析および現地で発生した離岸流セルの従 来の計測結果とは，定性的によい一致が見られた．実海 岸で観測された離岸流セルの形態と本研究で得られた離 岸流については無次元パラメー夕の関係においてほぼ一 致することを確認した。本計算モデルの現地観測との一 致性については現段階では満足できるものであった.

今後の課題としては, 地形変化と離岸流について定量 的な評価を行うこと, 実海域での離岸流発生の指標の作 成を行うことがあげられる。本研究では平面2次元のモ デルを用いて解析を行ったが, 離岸流の3 次元構造につ いても調べる必要がある.

本研究を行うにあたり科学研究費補助金（基盤研究 (B)，23360205代表者：関口秀雄）の補助を受けたこと を付記する。

\section{参 考 文 献}

椹木 亨 (1982)：漂砂と海岸侵食, 森北出版, 195 p.

第九管区海上保安部（2006）: 新潟県島見浜付近流況調查報告 書, $48 \mathrm{p}$.

出口一郎, 荒木進歩, 竹田怜史, 松見吉晴, 古河泰典 (2003)：鳥取県浦富海岸で観測された離岸流の特性, 第 50 回海講論文集, pp.151-155.

西 隆一郎，萩尾和央，山口博，岩根信也，杉尾 毅 （2003）：水難事故予防のための離岸流調査に関する基礎 的研究, 第 50 回海講論文集, pp.156-160.

日野幹雄 $(1974 \mathrm{a})$ : 海浜流系の発生理論, 土木学会論文報告 集, No.225, pp.17-29.

日野幹雄（1974 b）：応答性を考慮した海浜流系と海浜地形の 発生発達に関する理論, 土木学会論文報告集，No.237, pp.87-98.

細山田得三，大橋俊樹（2008）：海岸地形に依存した離岸流の 発生機構の基礎的数值実験, 第 55 回海講論文集, pp.86-90.

堀川清司 (1973) : 海岸工学, 東京大学出版会, $304 \mathrm{p}$.

Castelle, B., P. Bretel, S. Moreisset, P. Bonneton, M. Tissier, C. Sotin, A. Nahol, N. Bruneau, J.-P. Parisot, S. Capo, S. Bujan, V. Marieu (2009) : Rip current system over strong alongshore nonuniformities: on the use of HADCP for model validation, Journal of Coastal Research, SI 56, pp.1746-1750.

James A. Bailard (1981): An Energetics Total Load Sediment Transport Model For a Plane Sloping Beach, Jounal of Geophysical Reseach, Vol.86, No. C11. pp.10938-10954. 